\title{
The stimulating impact of elevated temperatures on growth and productivity of Parthenium hysterophorus L.
}

\section{Riti Thapar Kapoor}

Plant Physiology Laboratory, Amity Institute of Biotechnology, Amity University, Noida - 201 303, Uttar

Pradesh, India

\begin{abstract}
Invasive alien weeds pose a great threat to biodiversity by suppressing the native flora and causing negative impacts on crop yields. Parthenium hysterophorus is an exotic weed that causes nuisance and health hazard to mankind and animals, and is a danger to the environment. Experiments were conducted during summer and winter to understand the impact of different temperature conditions on the growth of Parthenium. Pot studies conducted at $22-30^{\circ} \mathrm{C}$ temperature conditions were considered as control. During summer at $35-45^{\circ} \mathrm{C}$, various growth parameters significantly increased in comparison to the $7-15^{\circ} \mathrm{C}$ temperature regime in winter. Different biochemical constituents were also higher in the leaves during summer than in winter season. The present investigation clearly indicates that growth and productivity of Parthenium was directly proportional to the increase in atmospheric temperature, indicating the possibility of the influence of rising temperature on its invasiveness.
\end{abstract}

Keywords: Climate change

\section{Introduction}

The process of economic development has resulted in large scale of environmental degradation across the world. Rapid industrialization, increases in greenhouse gases in the atmosphere, climate change, loss of biodiversity, deforestation and environmental pollution have all become matters of serious concern. Climate change is a global phenomenon, and increases in the global atmospheric concentration of carbon dioxide and other greenhouse gases beyond their natural level caused by anthropogenic activities are responsible for increases in the average temperature of the earth i.e. global warming. Global atmospheric carbon dioxide $\left(\mathrm{CO}_{2}\right)$ concentration is predicted to rise to $550 \mathrm{ppmv}$ by the middle of the present century (Prentice et al.2001) and it has been predicted that there will be reduction in rainfall in future in comparison to the present rainfall pattern. Such climatic changes will adversely affect the entire agricultural production system through direct or indirect effects on crops, livestock and pests, and there is also predicted to be significant changes in the distribution and abundance of certain kinds of weeds (Houghton et al.1990). The Intergovernmental Panel on Climate Change (IPCC) in its fourth assessment report indicated that many developing countries are more vulnerable to climate change because they largely depend on climate-sensitive sectors.

Invasive alien weeds are aggressive invaders outside their natural range, adversely affecting the proper utilization of land, biodiversity and environment. Weeds have a greater genetic diversity than crop plants and show positive responses to elevated temperature and carbon dioxide level in comparison to crop plants. Parthenium hysterophorus L. (Asteraceae), popularly known as gajar grass, carrot weed, feverfew, star weed and whitetop, is one of the top ten worst weeds in the world. Itis native to north-east Mexico, and was probably introduced to India along with wheat grains under the PL 480 scheme from USA; it has spread alarmingly to almost all the states in India. Growing in wasteland, roadsides, railway tracks, vacant sites and construction sites, it can reduce crop yields up to $40 \%$ (Khosla \& Sobti 1981). It begins to flower within a month of seedling emergence, and it can continue to flower profusely until senescence (Tamado et al. 2002). P.hysterophorus is considered a noxious weed because of its prolific seed production, plasticity in its physiological behaviour (Haseler1976), allelopathic

* Author for correspondence: email : drriti_bhu@yahoo.co.in 
effect on the neighbouring plants (Adkins \&Sowerby 1996), strong competitiveness with crops(Tamadoet al. 2002) and health hazard to humans (Pasricha 2010) as well as animals (Chippendale \&Panetta 1994).Because of these effects, it contributes to social and economic instability by placing constraints on sustainable development, economic growth and food security (Kohli et al. 2006).

Biochemical and molecular responses in plants under elevated temperature conditions are not well documented in the literature. However, a critical perusal of the literature revealed few reports on changes in growth and physiological processes of various crop plants exposed to different temperature regimes (Mavi \& Tupper 2004; Savicka\&Skute 2010; Ribeiro et al. 2012). All the growth stages of P.hysterophorus can be seen throughout the year, but it has been observed to grow very quickly during the summer season. This study was designed to provide data on comparative growth under different temperature regimes due to seasonal variation.

\section{Materials \& Methods}

The experiments were conducted at Amity University in Noida $\left(28^{\circ} 57^{\prime} \mathrm{N}, 77^{\circ} 32^{\prime} \mathrm{E}\right.$, elevation $200 \mathrm{~m}$ ), located $20 \mathrm{~km}$ southeast of New Delhi in Gautam Budh Nagar district of Uttar Pradesh state, India. Noida experiences three seasonsper year:summer (Apr-June), rainy (July- Aug) and winter (Nov-Feb). With an annual mean temperature of $25-33^{\circ} \mathrm{C}$, the mean maximum $\left(42.5^{\circ} \mathrm{C}\right)$ occurs in summer (May-June) and the mean minimum $\left(4.5^{\circ} \mathrm{C}\right)$ in winter (Dec- Jan).

The pot studies were conducted in the Botanical Garden of Amity University in Noida. Parthenium hysterophorus plants were grown under three different temperature regimes (seasons) (35-45,7-15and $\left.22-30^{\circ} \mathrm{C}\right)$ representing typical warm, cool and intermediate conditions respectively. Photoperiod was 10 hours and relative humidity was $65 \%$. Earthen pots $25 \mathrm{~cm}$ deep and $25 \mathrm{~cm}$ in diameter had their drainage holes plugged with cotton and these were filled with equal weights of a homogeneous mixture of $10 \mathrm{~kg}$ sandy loam soil and $80 \mathrm{gm}$ of diammonium phosphate. Ten viable seeds of Parthenium hysterophorus were sown per pot equidistantly on the surface and covered with a thin layer of soil. After 10 days, seedlings were thinned to five plants per pot in those pots which had more than five plants. The soil of each pot was thoroughly watered and then uniform watering was continued for upto 60 days.

Plant growth was recorded after 30 and 60 days by recording the number of seedlings per pot, number of leaves per plant, leaf length, plant height, number of branches per plant, number of capitula per plant and number of seeds per five capitula.

Different biochemical constituents present in the leaves were analyzed as follows. The amount of chlorophyll was determined by the method of Arnon (1949). 0.5 grams of fresh leaves were ground with $10 \mathrm{ml} 80 \%$ acetone and centrifuged at $3000 \mathrm{~g}$ for 10 mins. The volume of supernatant was recorded. The optical density was measured at 645 and $663 \mathrm{~nm}$, and the concentrations $\left(\mathrm{mg} \mathrm{g}^{-1}\right)$ of chlorophyll a, chlorophyll $\mathrm{b}$ and total chlorophyll calculated by using coefficients multiplied by the $\mathrm{OD}_{645}$ and $\mathrm{OD}_{663}$ readings (total chlorophyll [20.2, 8.02], chlorophyll a [12.7, -2.69], chlorophyll b [22.9, -4.68]) in the formula:

$$
\text { concentration }=\left[\mathrm{a}\left(\mathrm{OD}_{645}\right)+\mathrm{b}\left(\mathrm{OD}_{663}\right)\right] \cdot(\mathrm{V} / 1000 \mathrm{~W})
$$

where $\mathrm{V}$ is the volume of the supernatant in $\mathrm{ml}, \mathrm{W}$ is the fresh weight of the sample in grams, and OD is the optical density reading.

To estimate total soluble sugars, Parthenium leaves were harvested after 60 DAS and placed in an electric oven with forced air circulation at $70^{\circ} \mathrm{C}$ for $96 \mathrm{hr}$. The leaf dry matter was lyophilized and the leaf powder kept in glass containers in the dark at $15^{\circ} \mathrm{C}$ until biochemical analysis. Carbohydrate content was determined with $50 \mathrm{mg}$ of dry leaf powder incubated with 
$5 \mathrm{ml}$ of distilled water at $100^{\circ} \mathrm{C}$ for $30 \mathrm{~min}$. Subsequently the homogenized solution was centrifuged at $2000 \mathrm{~g}$ for $5 \mathrm{~min}$ at $20^{\circ} \mathrm{C}$ and the supernatant removed. Quantification of total soluble sugars was carried out at $490 \mathrm{~nm}$ according to the method of Dubois et al. (1956) using glucose as a standard.

Quantitative estimation of protein content was analyzed by the method of Lowry et al. (1951). Stock solution of the following reagents was prepared: alkaline sodium carbonate solution $\left(0.2 \% \mathrm{Na}_{2} \mathrm{CO}_{3}\right.$ in $\left.0.1 \mathrm{~N} \mathrm{NaOH}\right)$; copper sulphate - sodium potassium tartarate solution $\left(0.5 \% \mathrm{CuSO}_{4} .5 \mathrm{H}_{2} \mathrm{O}\right.$ in $1 \%$ sodium potassium tartarate); alkaline copper reagent (mixed $50 \mathrm{ml}$ of reagent $\mathrm{A}$ and $1 \mathrm{ml}$ of reagent $\mathrm{B}$ ); Folin-Ciocalteu reagent diluted with an equal volume of water just before use; $1 \mathrm{~N} \mathrm{NaOH} .0 .5$ grams fresh leaf material of Parthenium were homogenized with $1 \mathrm{ml}$ of $1 \mathrm{~N} \mathrm{NaOH}$ for 5 minutes at $100{ }^{\circ} \mathrm{C} .5 \mathrm{ml}$ of alkaline copper reagent were added to it and the mixture allowed to stand at room temperature for $10 \mathrm{~min}$. Then $0.5 \mathrm{ml}$ of Folin-Ciocalteu reagent were added immediately and mixed in the test tube. The absorbance of the solution was measured at $650 \mathrm{~nm}$ after $30 \mathrm{~min}$. The amount of protein was calculated with reference to a standard curve for lysozyme.

All the experiments were laid out in a complete randomized block design with three replicates (Snedecor 1957).

\section{Results}

In summer, seeds begin to germinate after five days, but in intermediate and winter seasons seed germination was delayed with fewer seedlings. Ten days after sowing, there were more seedlings in pots sowed in summer; numbers were reduced by almost a quarter in winter (Table 1). After 30 days, there were substantial differences in the various growth parameters, with every measurement greater for seeds sown in summer (Table 1).

The same patterns were evident for the various biochemical constituents (Table 1), with values in summer very different from those of winter.

\begin{tabular}{|c|c|c|c|c|}
\hline \multirow{2}{*}{$\begin{array}{l}\text { Days } \\
\text { after } \\
\text { sowing }\end{array}$} & \multirow[b]{2}{*}{ Variable } & \multicolumn{3}{|c|}{ Season (a proxy for temperature) } \\
\hline & & Winter & Intermediate & Summer \\
\hline 10 & Seedlings per pot & $5.62 \pm 0.45$ & $7.23 \pm 0.63$ & $9.16 \pm 0.94$ \\
\hline 30 & Leaves per plant & $5.95 \pm 0.57$ & $7.36 \pm 0.74$ & $9.52 \pm 0.87$ \\
\hline 30 & Leaf length $(\mathrm{cm})$ & $4.82 \pm 0.32$ & $6.84 \pm 0.63$ & $8.14 \pm 0.72$ \\
\hline 30 & Plant height $(\mathrm{cm})$ & $9.71 \pm 0.82$ & $10.72 \pm 0.88$ & $12.56 \pm 0.98$ \\
\hline 60 & Leaves per plant & $19.64 \pm 0.73$ & $23.95 \pm 0.93$ & $29.36 \pm 0.85$ \\
\hline 60 & Leaf length $(\mathrm{cm})$ & $10.45 \pm 0.09$ & $13.92 \pm 0.12$ & $15.12 \pm 0.23$ \\
\hline 60 & Plant height $(\mathrm{cm})$ & $31.73 \pm 0.25$ & $45.30 \pm 0.59$ & $54.95 \pm 0.46$ \\
\hline 60 & Number of branches per plant & $5.84 \pm 0.03$ & $7.31 \pm 0.08$ & $8.26 \pm 0.09$ \\
\hline 60 & Number of capitula per plant & $239 \pm 0.86$ & $275 \pm 0.96$ & $288 \pm 0.64$ \\
\hline 60 & Number of seeds per five capitula & $16 \pm 0.05$ & $23 \pm 0.07$ & $25 \pm 0.19$ \\
\hline 60 & Total chlorophyll content (mg/g) & $1.92 \pm 0.21$ & $2.73 \pm 0.38$ & $3.84 \pm 0.96$ \\
\hline 60 & Total soluble sugar $(\mathrm{mg} / \mathrm{g})$ & $1.93 \pm 0.16$ & $2.52 \pm 0.31$ & $3.46 \pm 0.87$ \\
\hline 60 & Protein content $(\mu \mathrm{g} / \mathrm{ml})$ & $71 \pm 0.52$ & $98 \pm 0.35$ & $123 \pm 0.94$ \\
\hline
\end{tabular}

Table 1: Effects of seasonal variation in temperature on growth parameters and biochemical constituents of Parthenium hysterophorus. 


\section{Discussion}

Climate change directly affects the population dynamics, invasive capacity and decline and extinction of plant species and it can provide opportunity for weeds to invade into new ecosystems. Temperature and atmospheric $\mathrm{CO}_{2}$ are considered as climatic variables that can alter plant invasiveness (Bradley et al. 2010). Parthenium hysterophorus L. is reported to be physiologically adaptable and thereby tolerant to wide range of temperature regimes, lower rainfall and elevated $\mathrm{CO}_{2}$ level (Hegde \& Patil 1980), as observed in the present investigation. Rising atmospheric temperature may give competitive advantage to $C_{4}$ plants over $C_{3}$ plants; the majority of weeds are $\mathrm{C}_{4}$ plants (Singh et al. 2011). Moore et al.(1987) and Tirumala Devi \& Raghavendra (1993) reported that Parthenium is a $C_{3}-C_{4}$ intermediate plant because the upper leaves seem to use the $\mathrm{C}_{3}$ photosynthetic pathway, while middle and basal leaves have the typical Kranz leaf anatomy associated with $\mathrm{C}_{4}$ photosynthesis. Parthenium is therefore likely to increase its growth in elevated temperature and $\mathrm{CO}_{2}$ concentrations.

A higher percentage of Parthenium seed germination was observed during summer. Ahlawat et al. (1979) reported that Parthenium seeds treated at $40^{\circ} \mathrm{C}$ for $24 \mathrm{~h}$ prior to germination brought down germination success to $40 \%$, whereas treatment at $90^{\circ} \mathrm{C}$ showed only $8 \%$ germination. Nguyen et al. (2010) have reported that the highest number of Parthenium seeds were produced under warm conditions, with a maximum number $(60 \%)$ of unfilled seeds under cool condition. Warm dry conditions allow reproduction after only 50 days of growth, while cool and wet conditions delay this to after 75 days. Warm conditions may therefore promote the reproductive ability of Parthenium by increasing seed production and the seed-fill percentage, producing seeds with the capacity to live longer in the soil seed bank. Higher temperature during seed development increases seed germinability in many species (Llorens et al. 2008). According to Long et al. (2008), warm temperature at the time of Parthenium seed production enables the seed once shed to persist in the soil for more than three years, whereas cool temperature permit survival for only 1 - 3 years.

Toh et al. (2011) reported that increased temperature enhances growth of Parthenium, enlarges canopy size and structure and accelerates population growth rate because of the shortened life cycle, supported by Entz \&Fowler (1991) in wheat and Pandey et al. (2003) in Parthenium. Singh \& Singh (2010) reported the extensive coverage of vacant cultivated land during summer by Parthenium. The growth-enhancing effects of $\mathrm{CO}_{2}$ enrichment will increase with increasing temperature,increasing water-utilization efficiency because of the large biomass (Idso 1990).

The findings of the present paper clearly indicate the inhibition of photosynthesis due to low light intensity and short photoperiod in winter, decreasing photosynthates probably because of decreased biosynthesis of chlorophyll - resulting in less biomass production in winter. Naidu \&Swamy (2009) reported that Eugenia jambolana, Terminalia arjuna and Chukrasia tabularis plants grown under high light intensity showed higher level of biochemical constituents such as carbohydrates, protein and lipids in all plant parts as compared to plants grown in low light intensity. Goodchild et al. (1972) also reported that shaded plants show lower protein content than plants grown in the sun; the low protein content in shade-grown plants is associated with lower activity of RUBPcarboxylase (Bjorkman 1968) and nitrate reductase (Naidu \&Swamy 1993). Similar results were observed in Erythrina variegate by Muthuchelian et al. (1989) and in Pongamia pinnata by Naidu \&Swamy (1993).

Hence the present study clearly indicates that Parthenium hysterophorus is likely to accelerate its growth under changing climatic conditions and it will become a more aggressive weed due to the warmer climatic conditions in future. The data of the present paper can help in development of predictive models of weed emergence in the agricultural lands and may 
generate significant information that can be useful for the development of integrated management strategies for the control of Parthenium.

\section{Acknowledgements}

The author thanks Prof. K. C. Upadhyaya, Advisor, Amity Institute of Biotechnology, Amity University, Noida, India for providing the necessary laboratory and library facilities.

\section{References}

Adkins SW \& Sowerby MS (1996)Allelopathic potential of the weed Parthenium hysterophorus L. in Australia. Plant Protection Quarterly 11: 20-23

Ahlawat AS, Dagar JC \& Singh VP (1979) Seed germination studies on Parthenium hysterophorus L. Proceedings of Indian National Science Academy B 45 (6): 613 - 616

Arnon DT (1949) Copper enzymes in isolated chloroplasts polyphenoloxidase in Beta vulgaris. Plant Physiology 24: $1-5$

Bjorkman O (1968) Carboxydismutase activity in shade adapted and sun adapted species of higher plants. Plant Physiology 21: 1-10

Bradley BA, Blumenthal DM, Wilcove DS \& Ziska LH (2010) Predicting plant invasions in an era of global change. Trends in Ecology \&Evolution 25: 310-318

Chippendale JF\& Panetta FD (1994) The cost of Parthenium weed in the Queensland cattle industry. Plant ProtectionQuarterly 9: 73-76

Dubois M, Gillas KA, Hamilton JK, Roberts PA \&Smith F (1956) Colorimetric method for determination of sugars and related substances. Analytical Chemistry 28: 350-356

Entz MH \& Fowler DB (1991) Agronomic performance of winter versus spring wheat. Agronomy Journal 83: 527-532

Goodchild OJ, Bjorkmann O \& Pyliotis NA (1972) Chloroplast ultrastructure, leaf anatomy and content of chlorophyll and soluble protein in rainforest species. Yearbook of the Carnegie Institution, Washington 71 : 102-107

Haseler WH (1976)Parthenium hysterophorous L. in Australia. Pest Articles \& News Summaries (PANS) 22: 515517

Hegde BA \& Patil TM (1980) Physiological studies on Parthenium hysterophorus L. under different ecological conditions. Biovigyanam6: 15-19

Houghton JT, Jenkins GJ \& Ephraums JJ (1990) Climate Change: the IPCC Scientific Assessment. Cambridge University Press, Cambridge

Idso SB (1990) Carbon dioxide and global change: earth in transition. IBR Press, Institute for Biospheric Research, Inc. Arizona, USA.

Khosla SN \& Sobti SN (1981)Effective control of Parthenium hysterophorus L. Pesticides 15:18-19.

Kohli RK, Batish DR, Singh HP \& Dogra K (2006) Status, invasiveness and environmental threats of three tropical American invasive weeds (Parthenium hysterophorus L., Ageratum conyzoides L., Lantana camara L.). Biological Invasions 8: 1501-1510

Llorens L, Pons M, Gil L \& Boira H (2008) Seasonality of seed production and germination trends of Fumana ericoides (Cistaceae) in the west semiarid Mediterranean region. Journal of Arid Environments 72: 121126

Long RL, Panetta FD, Steadman KJ, Bekker RM, Brooks S \& Adkins SW(2008) Seed persistence in the field may be predicted by laboratory- controlled aging. Weed Science 56: 523-528

Lowry OH, Rosebrough NJ, Fan AL \& Randal RJ (1951) Protein measurement with the Folin-phenol reagent. Journal of Biological Chemistry 193: 265-275

Mavi HS \& Tupper GJ (2004)Agrometeorology: principles and applications of climate studies in agriculture.HaworthPress. pp. 50 - 64

Moore BD, Franceschi VR, Cheng S, Wu J \& Ku MSB (1987) Photosynthetic characteristics of the $\mathrm{C}_{3}-\mathrm{C}_{4}$ intermediate Parthenium hysterophorus. Plant Physiology 85: 984 -989

Muthuchelian K, Paliwal K, Gnanam A \& Paliwal K (1989) Influence of shading on net photosynthetic and transpiration rate, stomatal diffusive resistance, nitrate reductase and biomass productivity of wood legume tree species (Erythrina variegata Lam.). Proceedings of Indian Academy of Sciences (Plant Sciences) 99 (6): 539-565

Naidu CV \& Swamy PM (1993) Effect of shade on growth, biomass production and associated physiological parameters in Pongamia pinnata L. Pierre. Indian Journal of Plant Physiology 36: 212-214

Naidu CV \& Swamy PM (2009) Effect of low light on lipid protein and carbohydrate content in different plant parts of some tropical decidous tree species. Journal of Indian Botanical Society 88(3\&4): 186 - 189 
Nguyen TLT, Navie SC \& Adkins SW (2010) The reproductive capacity of Parthenium weed under different climatic conditions. In Proceedings 17th Australasian Weeds Conference, Published by New Zealand Plant Protection Society (Ed. S. M. Zydenbos). $26-30^{\text {th }}$ September. pp. 124-127

Pandey DK, Palni LMS \& Joshi SC (2003) Growth, reproduction, and photosynthesis of ragweed Parthenium (Parthenium hysterophorus). Weed Science 51(2): 191-201

Pasricha JS (2010) The problem of Parthenium in India. In Proceedings: Scientific Presentations on Parthenium. Third International Conference on Parthenium, Indian Agricultural Research Institute, New Delhi pp. 4-6

Prentice IC, Farquhar GD \& Fasham MJR (2001) The carbon cycle and atmospheric carbon dioxide. In: Climate change 2001: the scientific basis. In: Houghton JT et al (eds) 3rd Assessment Report of the IPCC. New York: Cambridge University Press. pp. 183-239.

Ribeiro RV, Machado EC, Espinoza-Núñez E, Ramos RA \& Machado DF(2012)Moderate warm temperature improves shoot growth, affects carbohydrate status and stimulates photosynthesis of sweet orange plants. Brazilian Journal of Plant Physiology 24(1): 37- 46

Savicka M\& Skute N(2010) Effects of high temperature on malondialdehyde content, superoxide production and growth changes in wheat seedlings (Triticum aestivum L.). Ekologija 56: 26-33

Singh MK \& Singh RK (2010) Alien invasive weeds - an emerging threat to agricultural biodiversity in India. SAARC Workshop on Biodiversity Conservation, Sept 21- 22, Dept Plant Physiology, Institute of Agricultural Sciences, BHU, Varanasi. pp.91.

Singh RP, Singh RK \& Singh MK (2011) Impact of climate and carbon dioxide change on weeds and their management - a review. Indian Journal of Weed Science 43(1\&2): 1- 11

Snedecor W (1957)Statistical methods. Ames, USA : Iowa State University Press. pp. 594.

Tamado T, Schutz W \& Milberg P (2002) Germination ecology of the weed Partheniumhysterophorus in eastern Ethiopia. Annals of Applied Biology 140: 263-270

Tirumala Devi M \& Raghavendra AS (1993) Photorespiration in $\mathrm{C}_{3}-\mathrm{C}_{4}$ intermediate species of Alternanthera and Parthenium: reduced ammonia production and increased capacity of $\mathrm{CO}_{2}$ refixation in the light. Photosynthetic Research 38: 177-184

Toh R, Hanan J, Dhileepan K, Shivas RG \& Adkins SW (2011) Stimulation of Parthenium weed canopy under changing climate using L - systems. $19^{\text {th }}$ International Congress on Modelling \&Stimulation, Perth, Australia. $12-16^{\text {th }}$ December. pp. 1009-1015

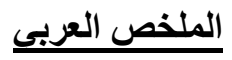

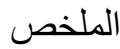

